\title{
Avaliação da eficácia do retalho cutâneo fibular para monitoração das microanastomoses em transferências microcirúrgicas da fíbula
}

\author{
Evaluation of the fibular cutaneous flap for monitoring the
} microanastomosis in microsurgical fibula transferences

Arnaldo V. Zumiotti ${ }^{1}$, Edgard N. França Bisneto ${ }^{2}$, Yussef A. Abdoun $I^{2}$, João C. Nakamoto ${ }^{3}, T_{\text {eng. }}$ H. Weil

\section{RESUMO}

O enxerto ósseo vascularizado tem sido utilizado com mais frequência nas últimas duas décadas, principalmente no tratamento de perdas ósseas extensas difíceis de serem tratadas com métodos convencionais. A viabilidade e a consequente hipertrofia do enxerto ósseo vascularizado depende da presença de microanastomoses pérvias. A monitoração das microanastomoses é extremamente importante no período pós-operatório para se identificar eventuais tromboses e dessa forma poder planejar a exploração cirúrgica precoce. Dentre os métodos disponíveis para esta avaliação a cintilografia óssea, a angiografia e a ultrassonografia convencional com aparelho tipo Doppler apresentam limitações pois fazem controles pontuais. A monitoração contínua, por outro lado, pode ser realizada com instrumentos através da medida do fluxo arterial com implantação de eletrodos acoplados ao ultrassom tipo Doppler, com eletrodos que medem temperatura e pela geração eletroquímica de hidrogênio local ou ainda clinicamente com o retalho cutâneo baseado em perfurantes da artéria fibular. Apesar de estarmos usando o retalho fibular como monitor das microanastomoses desde a sua descrição por Yoshimura, em 1983, existem controvérsias a respeito de sua eficácia. Por essa razão, desenvolvemos o presente trabalho com o objetivo de analisar a sensibilidade e a especificidade desse método para monitoração das microanastomoses em transplantes vascularizados da fíbula

Descritores: Fíbula vascularizada; Retalho cutâneo fibular; Microanastomoses.

\section{SUMMARY}

The use of free vascularized fibular graft (FVFG) is nowadays a common procedure for severe segmental bone loss. Thrombosis of the microanastomosis leads to a lack of bone incorporation of the FVFG unless a successful early exploration would have been performed. Due to this fact, the continuous monitoring of the FVFG viability in the immediate postoperative period needs to be executed. The use of a variety of methods has been proposed to asses the viability on an intermittent basis. These include selective angiography, monitoring of healing and hypertrophy with serial radiographs, bone scan and Doppler ultrasound scanning. Intermittent monitoring methods, however, will not detect acute thrombosis. Continuous monitoring is possible with instrumental methods such as the laser Doppler implants, the thermocouple probes, and the measurement of electrochemically or clinically produced hydrogen or using the fibular cutaneous flap that works as a buoy. Since the last method was proposed in 1993, we started to use it in our unit, but many controversies arised regarding its efficacy. For this reason we decided on the current study, to analyze the sensibility and the specificity of the fibular flap as a monitor of the microanastomosis in the FVFG.

Key words: Fibular flap; Free bone transfer; Microsurgery
Trabalho realizado no Departamento de Ortopedia e Traumatologia da Faculdade de Medicina da Universidade de São Paulo.

1- Prof. Associado e chefe da Disciplina de Traumatologia do Departamento de Ortopedia

2 - Médico estagiário do Grupo de Mão e Microcirurgia do DOT 3 - Médico residente do DOT da FMUSP

4 - Médico Assistente do Grupo de Mão e Microcirurgia do DOT

Endereço para correspondência: Rua Ovídio Pires de Campos, 333 3o andar - Cerqueira César - São Paulo -SP - CEP 05403-010
Work performed at the Orthopedics and Traumatology Department of the University of Sao Paulo School of Medicine.

1 - Associate Professor and Head of the Traumatology Discipline at the Orthopedics Department of FMUSP

2 - Trainee doctor at the Hand and Microsurgery Group of the FMUSP's DOT

3 - Resident doctor of the FMUSP's DOT

4 - Assistant Doctor of the Hand and Microsurgery Group of the FMUSP's DOT

Adress: Rua Ovídio Pires de Campos, 333 - 3 andar - Cerqueira César São Paulo -SP - CEP 05403-010 


\section{INTRODUÇÃO}

O enxerto ósseo vascularizado da fíbula tem sido utilizado com frequência no tratamento de perdas ósseas extensas decorrentes de causas pós-traumáticas, tumorais, infecciosas e ainda nas pesudartroses congênitas da tíbia e dos ossos do antebraço. Essa técnica baseia-se na retirada de um segmento ósseo da diáfise da fíbula juntamente com os vasos fibulares que serão responsáveis pela sua irrigação. Após a osteossíntese são realizadas as anastomoses microvasculares dos vasos fibulares nos vasos receptores. O sucesso da cirurgia depende da viabilidade da fíbula transferida, que por sua vez, necessita da presença de microanastomoses pérvias. A monitoração contínua das microanastomoses na primeira semana do período pósoperatório é essencial para se identificar precocemente a ocorrência de trombose arterial ou venosa e se realizar o mais rápido possível a sua correção. O controle pós-operatório das anastomoses microvasculares pode ser feito com o emprego de cintilografia óssea, arteriografia e ultrassografia com Doppler. Porém esses métodos fazem controles pontuais não sendo úteis para diagnosticar tromboses agudas durante as duas primeiras semanas do período pós-operatório (17). Os métodos que fazem a monitoração contínua necessitam da implantação de eletrotodos especiais para medida do fluxo arterial através de ultrassonografia com Doppler ${ }^{(7,9,10)}$ ou da medida da temperatura ${ }^{(5)}$ ou ainda da produção eletroquímica de hidrogênio ${ }^{(8)}$. Esses métodos, embora eficazes, necessitam de aparelhos especiais e não estão disponíveis em nosso meio. Por outro lado, a monitoração com o retalho cutâneo baseado em perfurantes da artéria fibular é um método simples, sem custo e que depende apenas do exame clínico sistemático do retalho. Apesar dessas vantagens, existem controvérsias quanto a sua eficácia particularmente nos casos em que o retalho apresenta alterações da perfusão sanguínea. Por essa razão, no presente trabalho analisamos a sensibilidade e a especificidade do retalho cutâneo fíbular para monitoração das microanastomoses nas transferências microcirúrgicas da fíbula.

\section{CASUÍSTICA E MÉTODOS}

Foi realizado um estudo prospectivo das transferências microcirúrgicas da fíbula realizadas no Instituto de Ortopedia e Traumatologia do Hospital das Clínicas da Faculdade de Medicina da Universidade de São Paulo e no Hospital Sírio Libanês (SP), no período de 1985 a 2000, com o objetivo de analisar a eficácia do retalho cutâneo fibular para monitoração das microanastomoses. Foram considerados os seguintes critérios de inclusão para seleção dos pacientes :

1 - presença de afecções ósseas inelegíveis para o tratamento ortopédico convencional, tais como: pseudartrose congênita da tíbia ou dos ossos do antebraço e perdas segmentares ósseas extensas em sequelas de traumas, infeção ou tumores.

2 - emprego de enxertos vascularizados da fíbula associado ao retalho cutâneo fibular utilizado como monitor das anastomoses microvasculares

3 - controle da viabilidade da fíbula com cintilografia óssea até a segunda semana do período pós-operatório

4 - documentação radiográfica pós-operatória para estudo da hipertrofia da fíbula. Os critérios de exclusão contemplaram todas transferências microcirúrgicas da fíbula que não apresentavam o retalho cutâneo fibular e os casos com ausência de cintilografia óssea até o final da segunda semana do período pós-operatório ou sem estudo radiológico suficiente para documentar a hipertrofia da fíbula.

Dos 41 pacientes selecionados nesse estudo, 27 eram do sexo masculino e 14 do feminino. O tempo mínimo de seguimento foi de 3 anos. A idade variou de 2 a 38 anos com a média de 13 anos. As

\section{INTRODUCTION}

The vascularized bone graft of the fibula has been used frequently in the treatment of segmental bone losses resulting from post-traumatic, tumorous, and infectious causes, and also still in the congenital pseudoarthrosis of the shinbone and of the bones of the forearm. That technique is based on the retreat of a bone segment of the diaphysis of the fibula, together with the fibular vessels that will be responsible for its irrigation. The microvascular anastomosis of the fibular vessels into the receiving vessels is carried out after the osteosynthesis. The success of the surgery depends on the viability of the transferred fibula that, on its turn, needs the presence of pervious microanastomosis. The continuous monitoring of microanastomosis in the first week of the postoperative period is essential for the early identification of the occurrence of arterial or veined thrombosis and to correct this as soon as possible. The postoperative control of the microvascular anastomosis can be made using bone scintigraphy, arteriography and Doppler ultra-sound. However those methods make punctual controls and are not useful to diagnose acute thromboses during the first two weeks of the postoperative period ${ }^{(17)}$. The methods that make the continuous monitoring need the implantation of special electrodes for measuring arterial flow through a Doppler ultrasound ${ }^{(7,9,10)}$ or for measuring the temperature ${ }^{(5)}$, or still for the electrochemical production of hydrogen ${ }^{(8)}$. Those methods, although effective, need special appare/s and are not available in our area. On the other hand, the monitoring with the cutaneous flap based on perforators of the fibular artery is a simple method, without costs and that just depend on the systematic clinical exam of the flap. In spite of those advantages, there are controversies as to its effectiveness particularly in the cases in that the flap presents alterations of the blood perfusion. For that reason, in the present study we analyzed the sensibility and the specificity of the fibular cutaneous flap for monitoring the microanastomosis in the microsurgical transfers of the fibula.

\section{CASUISTRY AND METHODS}

During the period from 1985 to 2000, a prospective study of the microsurgical transfers of the fibula was performed at the Institute of Orthopedics and Traumatology of the Hospital das Clinicas of the School of Medicine of the University of Sao Paulo and in the Lebanese Syrian Hospital (SP), with the objective of analyzing the effectiveness of the fibular cutaneous flap for the monitoring of the microanastomosis. The following inclusion criteria were considered for the patients' selection:

1 - presence of bone infections ineligible for the conventional orthopedic treatment, such as: congenital pseudoarthrosis of the shinbone or of the bones of the forearm and extensive segmental bone losses in sequels resulting from traumas, infection or tumors;

2 - the use of vascularized grafts of the fibula associated to the cutaneous flap used as a monitor of microvascular anastomosis;

3 - the control of the viability of the fibula with bone scintigraphy until the second week of the postoperative period;

4 - the postoperative radiographic documentation for studying the fibula hypertrophy. The exclusion criteria contemplated all microsurgical transfers of the fibula that didn't present the fibular cutaneous flap and, in the cases with absence of bone scintigraphy up to the end of the second week of the postoperative period, or without enough radiological studies to document the fibula hypertrophy.

From the 41 patients selected in that study, 27 were males and, 14 females. The minimum follow-up period was of 3 years. Age varied from 2 to 38 years of age, with an average of 13 years. The affections and 
afecções e o respectivos números de pacientes nos quais foi realizado o enxerto vascularizado da fíbula estão relacionados abaixo.

\author{
Pseudartrose congênita da tíbia - 20 \\ Pseudartrose congênita dos ossos do antebraço - 2 \\ Pseudartrose pós-traumática da tíbia - 6 \\ Pseudartrose pós-traumática do rádio ou ulna - 5 \\ Pseudartrose por osteomielite hematogênica aguda da tíbia -2 \\ Pseudartrose pós-traumática do úmero- 2 \\ Pseudartrose após ressecção tumoral da tíbia- 2 \\ Pseudartrose após ressecção tumoral do úmero -1 \\ Pseudartrose pós-traumática do femur- 1
}

Os pacientes foram operados com anestesia geral com duas equipes cirúrgicas atuando simultaneamente, enquanto uma preparava a área receptora, a outra procedia a dissecção do enxerto vascularizado da fíbula. A fíbula foi exposta por meio incisão realizada na projeção do espaço entre os músculos solear e fibular longo ${ }^{(1,14)}$. Após osteotomia proximal da fíbula, os vasos fibulares foram dissecados e ligados próximos ao tronco tíbio-fibular. Em seguida, realizou-se a osteotomia distal da fíbula e ligadura dos vasos fibulares distalmente. Na dissecção do retalho cutâneo fibular foram incluidas uma ou duas perfurantes previamente identificadas com ultrassom tipo Dopler. Em 35 casos o retalho cutâneo foi mantido unido à fíbula por meio do septo crural posterior(Figura 1) e em 6 as suas perfurantes foram esqueletizadas em todo o seu trajeto. (Figura 2 ). A área doadora foi fechada por sutura direta em 30 casos, sendo complementada com enxerto de pele em 11.

$\mathrm{Na}$ área receptora, foi realizado desbridamento, com ressecção de tecido ósseo e de partes moles de má qualidade, e a dissecção dos vasos receptores. As suturas vasculares foram feitas com técnica microcirúrgica com nailon monofilamentado 9 ou 10 zeros. Em pacientes portadores de Pseudartrose Congênita da Tíbia e dos ossos do antebraço a artéria fibular do pedículo vascular foi reconstruida com o emprego de duas anastomoses término-terminais, uma proximal e outra distal. Nas pseudartroses do úmero e do femur a anastomose arterial foi término-lateral, respectivamente, na artéria umeral e na artéria femoral superficial. Nas veias fibulares as anastomoses foram em todos os casos do tipo término-terminal com as veias receptoras.

O controle das microanastomoses foi realizado clinicamente por meio da observação da coloração do retalho cutâneo fibular e de sua perfusão com o emprego do teste do reenchimento capilar. A suspeita de trombose arterial era feito quando o retalho apresentava palidez ao invés de sua coloração rósea característica e também havia ausência de perfusão arterial no teste do reenchimento capilar. Na trombose venosa o retalho cutâneo apresentava-se edemaciado e cianótico e com o teste do reenchimento capilar negativo. Nesses casos procedeu-se a exploração das microanastomoses e se ao final do procedimento o retalho voltava a ter perfusão normal era mantido, caso contrário efetuava-se a sua retirada. A avaliação da viabilidade da fíbula transplantada foi realizada com cintilografia óssea com metildifosfonato marcado com o isótopo 99 metaestável do Tecnécio ( $99 \mathrm{~m}$ Tc-MDP). Em todos os pacientes o exame foi realizado até o final da segunda semana do período pós-operatório, tomando-se o cuidado de não informar ao médico radiologista o desfecho clínico do retalho cutâneo da fíbula (Figuras 3 a e 3 b). the respective numbers of patients in whom the vascularized graft was implanted are listed below.

\section{Tibial congenital pseudoarthrosis - 20}

Congenital pseudoarthrosis of the forearm bone-2

Tibial post-traumatic pseudoarthrosis - 6

Post-traumatic pseudoarthrosis of the radio or the ulna - 5

Pseudoarthrosis per acute hematogenic tibial osteomyelitis -2

Post-traumatic pseudoarthrosis of the humerus - 2

Pseudoarthrosis after tumoral resection of the tibial- 2

Pseudoarthrosis after tumoral resection of the humerus -1

Post-traumatic pseudoarthrosis of the femur- 1

The patients were operated with general anesthesia with two surgical teams acting simultaneously. While one prepared the receiving area, the other proceeded with the dissection of the vascularized graft of the fibula. The fibula was exposed by means of an incision executed in the projection of the space between the soleus and the long fibular muscles ${ }^{(1,14)}$. After the proximal osteotomy of the fibula, the fibular vases were dissected and connected close to the tibial-fibular trunk. Soon afterwards, the distal osteotomy of the fibula was executed, as well as the distal bondage of the fibular vases. In the dissection of the fibular cutaneous flap one or two perforates, previously identified with a Doppler ultrasound, were included. In 35 cases the cutaneous flap was maintained connected to the fibula by the posterior crural septum (Figure 1), and in 6 cases the perforators were skeletized in their entire itinerary. (Figure 2). The donor area was closed by direct suture in 30 cases, and complemented with a skin graft in 11 cases.

A debridement was executed at the receiving area, with the resection of the bone tissue and of the bad quality soft parts, and with the dissection of the receiving vases. The vascular sutures were made with microsurgical technique with monofilament nylon 9 or 10 zeros. The fibular artery of the vascular pedicle was rebuilt with the utilization of two end-terminal anastomosis, one proximal and other distal, in patients with Congenital pseudoarthrosis of the Shinbone and of the bones of the forearm. In the pseudoarthrosis of the humerus and of the femur, the arterial anastomosis was end-lateral, respectively, in the humeral artery and in the superficial femoral artery. In the fibular veins the anastomosis was, in all the cases, of the end-terminal type with the receiving veins.

The control of the microanastomosis was executed clinically by the observation of the coloration of the fibular cutaneous flap and of its perfusion, using capillary refill test. The suspicion of arterial thrombosis was observed when the flap presented paleness instead of its rosy characteristic coloration, and there was also absence of arterial perfusion during capillary refill test. In the veined thrombosis the cutaneous flap showed edematization and cyanotic, and with a negative capillary refill test. In those cases the exploration of the microanastomosis was executed and, if at the end of the procedure the flap had normal perfusion again it was maintained, otherwise it was removed. The evaluation of the viability of the transplanted fibula was performed by bone scintigraphy with methyldiphosphate marked with the technetium-99 metastable isotope (99m TC-MDP). In all of the patients the exam was made until the end of the second week of the postoperative period, taking care not to inform the radiology doctor of the clinical result of the cutaneous flap of the fibula (Figure 3 a and 3 b). 


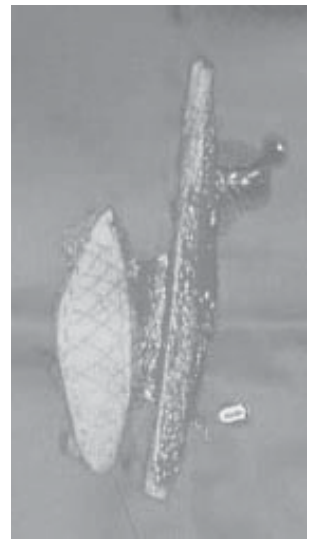

Figura 1 - Aspecto do retalho de pele (monitor) unido à fíbula vascularizada pelo septo crural posterior.

Figure 1 - Aspect of a skin flap (monitor) united to the vascularized fibula by the posterior crural septum.

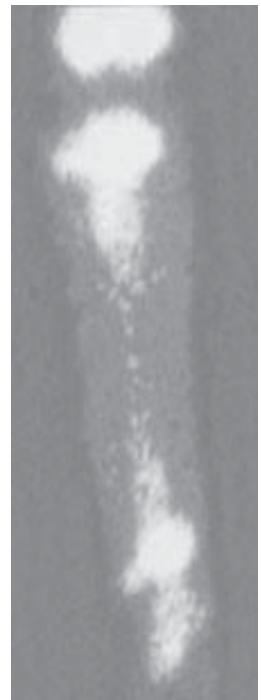

Figura 3 a - Cintilografia óssea mostrando captação do radiofármaco pela fíbula vascularizada.

Figure 3 a - Bone scintigraphy showing the capture of the radiopharmaceutical by the vascularized fibula.

A presença ou ausência de hipertrofia da fíbula documentada com radiografias seriadas foi utilizada como parâmetro tardio da viabilidade do enxerto vascularizado da fíbula .

\section{RESULTADOS}

Em 35 pacientes o retalho cutâneo da fíbula apresentou coloração e perfusão normais(Figura 4)(Tabela 1). Foram detectadas alterações da sua coloração e da sua perfusão em 6 casos, sendo confirmada por inspecção cirúrgica a trombose arterial em 2 e a venosa em 4 pacientes(Fig ura 5) (Tabela 2). Desses 6 pacientes re-operados em apenas 3 conseguiu-se a reperfusão do retalho cutâneo ao final da exploração cirúrgica ( Tabela 3). Nos demais o retalho foi retirado pois ao final da exploração das microanastomoses não se obteve a sua perfusão. A cintilografia realizada até a segunda semana do período

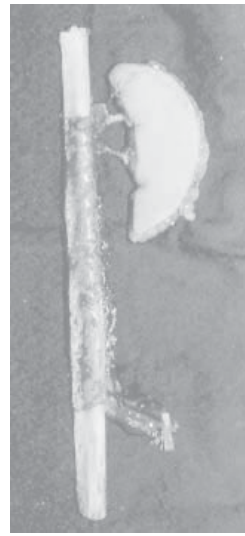

Figura 2 - Detalhe do retalho de pele (monitor) com a dissecção das artérias septocutâneas.

Figure 2 - Detail of the skin flap (monitor) with the desiccation of the septiocutaneous arteries.

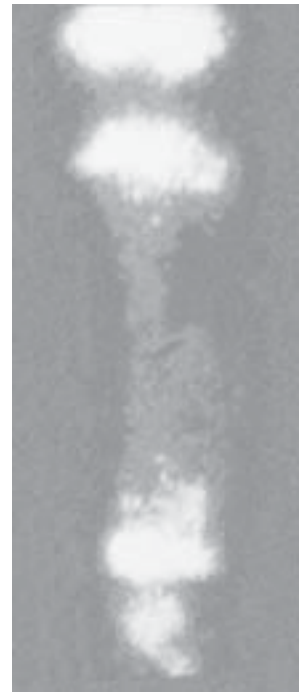

Figura 3 b - Cintilografia óssea mostrando ausência de captação da fíbula vascularizada.

Figure $\mathbf{3} \boldsymbol{b}$ - Bone scintigraphy showing the absence of capture of the vascularized fibula.

The presence or absence of fibula hypertrophy documented with serial $x$-rays was used as a late parameter of the viability of the vascularized graft of the fibula.

\section{RESULTS}

In 35 patients the cutaneous flap of the fibula presented normal coloration and perfusion (Figure 4) (Table1). Alterations of the coloration and perfusion were detected in 6 cases, confirming by surgical inspection the arterial thrombosis in 2 cases and the veined thrombosis in 4 patients (Figure 5) (Table 2). From those 6 patients operated again, in only 3 the reperfusion was accomplished for the cutaneous flap at the end of the surgical exploration (Table 3). On the remaining cases the flap was removed, because at the end of the exploration of the microanastomosis the perfusion was not accomplished. In the 38 cases that 


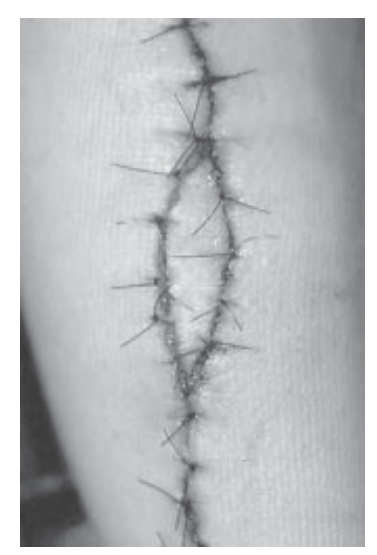

Figura 4 - Aspecto clínico do retalho de pele (monitor) mostrando coloração normal. Nesse caso o teste de reenchimento capilar foi normal.

Figure 4 - Clinical aspect of the skin flap (monitor), showing a normal coloration. In this case, the capillary refilling test was normal.

\begin{tabular}{|c|c|c|}
\hline Perfusão normal & Palidez/lsquemia & Cianose \\
\hline Normal perfusion & Pallor/Ischemia & Cyanosis \\
\hline 35 & 2 & 4 \\
\hline
\end{tabular}

Tabela 1- Distribuição dos desfechos clínicos dos retalhos cutâneos da fíbula quanto a sua viabilidade no período pósoperatório imediato.

Table 1 - Distribution of the clinical outcomes of the fibula cutaneous flaps concerning its viability during the immediate postoperative period.

\begin{tabular}{|c|c|c|}
\hline $\begin{array}{c}\text { Tipo de obstrução vascular } \\
\text { Type of vascular obstruction } \\
\text { Sucesso/ sucess(\%) }\end{array}$ & $\begin{array}{c}\text { Trombose arterial } \\
\text { Arterial thrombosis } \\
1(50 \%)\end{array}$ & $\begin{array}{c}\text { Trombose venosa } \\
\text { Veined thrombosis }\end{array}$ \\
\hline
\end{tabular}

Tabela 3 - Desfechos clínicos do retalho cutâneo fibular (monitor de pele) após exploração cirúrgica das microanastomoses.

Table 3 - Clinical outcomes of the fibular cutaneous flap (skin monitor) after surgical exploration of the microanastomosis.

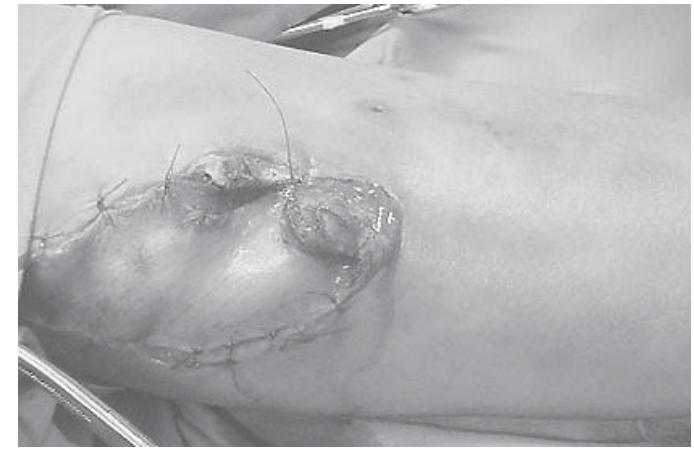

Figura 5 - Aspecto clínico do retalho de pele (monitor) mostrando cianose, sugerindo obstrução venosa.

Figure 5 - Clinical aspect of the skin flap (monitor) showing cyanosis, suggesting there is a venous obstruction.

\begin{tabular}{|c|c|}
\hline Trombose arterial & Trombose venosa \\
\hline Arterial thrombosis & Veinedthrombosis \\
\hline 2 & 4 \\
\hline
\end{tabular}

Tabela 2 - Correlação entre as alterações da perfusão do retalho cutâneo fibular e as obstruções vasculares detectadas por exploração cirúrgica .

Table 2 - Correlation between the alterations of the perfusion of the fibular cutaneous flap and the vascular obstructions detected by surgical exploration.

\begin{tabular}{|c|c|}
\hline Captante & Não captante \\
Uptaking & Non-uptaking \\
38 & 3 \\
\hline
\end{tabular}

Tabela 4 - Resultados das cintilografias ósseas realizadas até a segunda semana do período pós-operatório.

Table 4 - Results of the bone scintigraphies performed up to the second week of the postoperative period.

\begin{tabular}{|c|c|}
\hline $\begin{array}{c}\text { Com hipertrofia } \\
\text { With hypertrophy }\end{array}$ & $\begin{array}{c}\text { Sem hipertrofia } \\
\text { Without hypertrophy } \\
38\end{array}$ \\
38 \\
\hline
\end{tabular}

Tabela 5 - Estudo da hipertrofia da fíbula transplantada documentada por radiografias seriadas.

Table 5 - Study of the transplanted fibula hypertrophy, documented by serial $x$-rays.

pós-operatório demonstrou presença de captação na fibula transplantada nos 38 casos em que o retalho sobreviveu (uma trombose arterial e duas venosas foram revertidas após a exploração microcirúrgica) (Tabela 4). Em 2 casos de trombose venosa e em 1 de trombose arterial apesar da exploração cirúrgica não se conseguiu a revascularização da fíbula comprovada pela não reperfusão do retalho cutâneo, pela ausência de captação na cintilografia óssea e por ausência de hipertrofia no pós-operatório tardio (Tabela 5).

\section{DISCUSSÃO}

A monitoração contínua pós-operatória dos transplantes microcirúrgicos da fíbula é muito importante para se realizar o diagnóstico de eventual obstrução das microanastomoses e assim poder planejar a exploração cirúrgica precoce ${ }^{(1,13,14)}$. Os métodos que fazem essa avaliação de forma pontual não são adequados por serem insuficientes para surpreender trombose aguda das microanastomose ${ }^{(1)}$. Para the flap survived, the scintigraphy taken until the second week of the postoperative period demonstrated the presence of an uptake in the transplanted fibula (an arterial thrombosis and two veined were reverted after the microsurgical exploration) (Table 4). In 2 cases of veined thrombosis and in 1 of arterial thrombosis, in spite of the surgical exploration the proven revascularization of the fibula was not achieved due to the non-reperfusion of the cutaneous flap, due to the uptake absence in the bone scintigraphy, and due to the absence of hypertrophy during the late postoperative period (Table 5).

\section{DISCUSSION}

The postoperative continuous monitoring of the microsurgical transplants of the fibula is very important in order to construct the diagnosis of an eventual obstruction of the microanastomosis and, thus, to plan the precocious surgical exploration ${ }^{(1,13,14)}$. The methods that make that evaluation in a punctual way are not appropriate because they are 
a avaliação da viabilidade dos retalhos microcirúrgicos cutâneos e musculocutâneos o exame clínico periódico tem sido suficiente para a monitoração das microanastomoses $(2,4,5)$. A estratégia para esse controle baseia-se na confecção de uma janela no curativo para permitir o exame do retalho e dessa forma observar a sua coloração e realizar o teste do reenchimento capilar para o controle da perfusão sanguínea. Quando ocorre trombose arterial das microanastomoses o retalho apresenta-se com aspecto pálido ao contrário da sua coloração rósea característica, além de evidentes sinais de isquemia demonstrado pelo teste de reenchimento capilar. Se persistirem dúvidas lançamos mão do teste do sangramento realizado por manipulação das bordas do retalho ou através de sua perfuração com uma agulha. $\mathrm{Na}$ trombose venosa o retalho apresenta-se cianótico e a velocidade de reenchimento capilar torna-se muito rápida. Essas medidas são perfeitamente suficientes para monitorar continuamente o retalho no período pós-operatório, exceto quando ocorrem alterações clínicas concomitantes, tais como, hipotensão, hipovolemia ou anemia intensa. Se essas alterações forem detectadas é imperiosa a sua correção evitando-se assim explorações cirúrgicas desnecessárias. Isto nos obriga a realizar uma tarefa intransferível que é a de efetuar o exame do retalho, pelo menos, a cada 6 horas ou a cada 4, nos casos de prognóstico reservado.

Alguns métodos de monitoração contínua foram desenvolvidos para detectar alterações do fluxo sanguíneo por trombose venosa ou arterial das microanastomoses e baseiam-se em medidas transcutâneas da oxigenação capilar ou da temperatura ${ }^{(4)}$. Foram desenvolvidos também aparelhos de ultrassom tipo Doppler que são alimentados por informações captadas por eletrodos implantados próximo das microanastomoses ${ }^{(6,8,9)}$. Em nosso meio, não temos utilizado esses recursos para controle da viabilidade dos retalhos microcirúrgicos por serem métodos que utilizam aparelhos importados, que envolvem custos elevados, além de necessitarem de manutenção frequente. Outra desvantagem é a possibilidade de resultados falsos positivos levando a exploração cirúrgica desnecessária ${ }^{(6,8,9)}$. A dificuldade na monitoração das transferências microcirúrgicas da fíbula perdurou até a publicação por Yoshimura et al. ,em 1983, do retalho cutâneo fibular (12). Por ser nutrido por ramos diretos da artéria fibular esse retalho reflete as alterações do fluxo sanguíneo ocorridas por trombose arterial ou venosa. Nesse trabalho os autores relatam apenas 1 caso de necrose do monitor de pele em 17 pacientes operados e que apesar da exploração cirúrgica não houve reversão da oclusão vascular. As controvérsias sobre a eficácia do retalho fibular como monitor das microanastomoses ocorrem particularmente nos casos de alteração da sua coloração e da sua perfusão podendo caracterizar na opinião dos críticos desse método resultados falsos positivos. A inviabilidade do retalho cutâneo poderia significar, portanto, falha técnica na sua retirada, mal posicionamento ou compressão de seu pedículo vascular. É evidente que essas hipóteses encontram algum respaldo teórico porém tem pouco significado prático se considerarmos que o rigor na aplicação da técnica cirúrgica incluem todos os tempos operatórios, tais como, a dissecção do retalho osteocutâneo da fíbula, a estabilização esquelética, o posicionamento adequado do retalho cutâneo e a realização das microanastomoses. Agindo dessa forma, o retalho cutâneo fibular pode ser considerado um monitor fidedigno do fluxo sanguíneo do enxerto vascularizado da fíbula ${ }^{(14)}$

As artérias perfurantes no terço proximal da perna fazem um trajeto através do músculo fibular longo enquanto aquelas do terço médio e distal são septocutâneas verdadeiras ${ }^{(3)}$. Para não ocorrer dificuldade no exame clínico do retalho é aconselhável que as suas dimensões sejam de no mínimo $2 \mathrm{~cm}$ de comprimento por $1 \mathrm{~cm}$ de largura (Figura 6). Essas dimensões permitem o fechamento primário da área doadora. Algumas vezes devido a má qualidade do revestimento cutâneo da área receptora optamos pela retirada de um retalho de maiores insufficient to surprise the acute thrombosis of the microanastomosis (1). The periodic clinical examination for the evaluation of the viability of the cutaneous microsurgical and musculocutaneous flaps has been enough for monitoring the microanastomosis ${ }^{(2,4,5)}$. The strategy for that control is based on a window opened on the bandage to allow the exam of the flap and, in that way, to observe its coloration and to perform the capillary refill test for the control of blood perfusion. When the arterial thrombosis of the microanastomosis occurs, the flap presents a pale aspect, unlike its characteristic rosy coloration, in addition to evident ischemia signs demonstrated by the capillary refill test. The bleeding test should be performed in the case any doubts persist, manipulating the edges of the flap, or perforating the flap with a needle. In the veined thrombosis the flap presents is cyanotic and the speed of capillary refill becomes very fast. Those measurements are perfectly enough to monitor the flap continually in the postoperative period, except when there are concomitant clinical alterations, such as, hypotension, hipovolemy or intense anemia. If those alterations are detected their correction is mandatory to avoid unnecessary surgical explorations. This forces us to perform an untransferable task, which is the task of making the exam of the flap, at least, every 6 hours or at every 4 hours, in the cases of a reserved prognostic.

Some continuous monitoring methods were developed to detect alterations to the blood flow for the veined or arterial thrombosis of the microanastomosis, and they are based on transcutaneous measurements of the capillary oxygenation, or of the temperature ${ }^{(4)}$. Doppler ultrasound apparatus that receive information captured by electrodes implanted near the microanastomosis were also developed ${ }^{(6,8,9)}$. In our environment we have not been using these resources for the control of the microsurgical flaps, because they are methods that use imported apparels, which involve high costs, in addition to their need for frequent maintenance. Another disadvantage is the possibility of false positive false resulting in the unnecessary surgical exploration ${ }^{(6,8,9)}$. The difficulty in the monitoring of the microsurgical transfers of the fibula lasted until the publication by Yoshimura et al., in 1983, of the fibular cutaneous flap ${ }^{(12)}$. For being nurtured by direct branches of the fibular artery that flap reflects the alterations of the blood flow occurred due to arterial or veined thrombosis. In that work the authors report only 1 case of necrosis of the skin monitor in 17 operated patients and that, in spite of the surgical exploration, there was no reversion of the vascular occlusion. The controversies about the effectiveness of the fibular flap as a monitor of the microanastomosis arise particularly in the cases of color alteration and of perfusion and could characterize - in the opinion of the method's critics - false positive results. The unfeasibility of the cutaneous flap could mean, therefore, a technical flaw during its removal, or that it is badly positioned or there is a compression to its vascular pedicle. It is evident that those hypotheses find some theoretical support. However they have little practical meaning if we consider that the rigidity in the application of the surgical technique includes all of the operative times, such the dissection of the osteocutaneous flap of the fibula, the skeletal stabilization, the appropriate positioning of the cutaneous flap and the microanastomosis. As such, the fibular cutaneous flap can be considered a trustworthy monitor of the blood flow of the vascularized graft of the fibula ${ }^{(14)}$

The perforator arteries in the third proximal of the leg make an itinerary through the long fibular muscle, while those in the medium and distal thirds and are truly septiocutaneous ${ }^{(3)}$. In order to avoid any difficulties in the medical examination of the flap, it is advisable that its dimensions should have, at least, $2 \mathrm{~cm}$ of length and $1 \mathrm{~cm}$ of width (Figure 6). Those dimensions allow the closing of the primary donor area. Sometimes due to the bad quality of the cutaneous covering of the receiving area, we opted for the removal of a larger flap, for the simultaneous repairing of the bone loss and of the cutaneous covering ${ }^{(13)}$ (Figure 7). Under these circumstances the donorarea should be repaired 
dimensões para a reparação simultânea da perda óssea e da cobertura cutânea ${ }^{(13)}$ (Figura 7) Nessas circunstâncias a área doadora deve ser reparada com enxerto de pele. A manutenção do septo crural posterior no retalho osteocutâneo da fíbula não é obrigatória podendose mapear com ultrassom tipo Doppler uma ou mais perfurantes e incluí-las no retalho. A presença do septo crural posterior cria maior proteção para o retalho impedindo a torção das artérias perfurantes, porém diminui o arco de rotação dificultando o seu posicionamento nas reconstruções mais profundas como as do fêmur e do úmero. Outra opção para evitar o uso do septo crural posterior é realizar a inclusão de perfurantes do terço proximal ou médio da perna que apresentam maior comprimento e portanto maior arco de rotação.

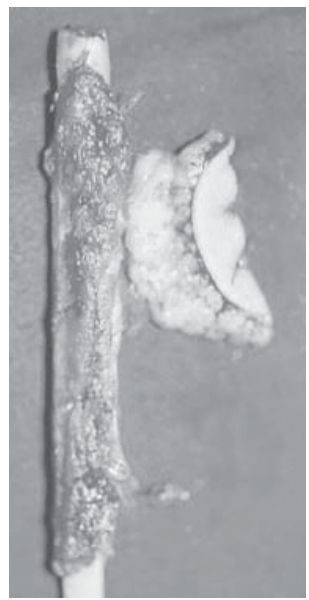

Figura 6 - Aspecto clínico das dimensões mínimas $(2 \mathrm{~cm} \times 1 \mathrm{~cm})$ do retalho de pele (monitor).

Figure 6 - Clinical aspect of the minimum dimensions $(2 \mathrm{~cm} x$ $1 \mathrm{~cm})$ for the skin flap (monitor).

A cintilografia óssea e as radiografias seriadas foram utilizadas, respectivamente, como métodos de avalição precoce e tardio da viabilidade da fíbula vascularizada ${ }^{(1)}$. Empregada com essa finalidade a cintilografia óssea deve ser feita até o final da segunda semana do período pós-operatório para evitar o efeito da revascularização do enxerto ósseo feita pelo leito receptor ("creeping substitution"). Nesse período a captação pelos osteócitos do radiofármaco demonstra que a viabilidade do enxerto ósseo é dependente exclusivamente da presença de fluxo sanguíneo decorrente de microanastomoses pérvias. A hipertrofia óssea obsevada nas radiografias seriadas ocorre segundo os princípios da lei de Wolf e somente é notada quando a fíbula encontra-se viável (Figuras 8, 9 e 10). Na reconstrução dos ossos do antebraço a hipertrofia óssea é menos evidente, ao contrário do observado no femur, na tíbia e no úmero, onde as radiografias seriadas demonstraram claramente esse fenômeno. A consolidação óssea não foi utilizada como método de avaliação da viabilidade da fíbula por poder ocorrer mesmo nos casos de obstrução das microanastomoses. A análise dos resultados demonstrou perfeita correlação entre o desfecho clínico do retalho cutâneo fibular e os achados intra-operatórios. A cintilografia óssea e as radiografias seriadas foram úteis para comprovar esses achados. O estudo estatístico revelou que a sensibilidade e a especificidade do retalho cutâneo fibular no presente trabalho foram , respectivamente , 98,6\% e 91,7\% para um nível de significância de 5\% (Tabela 6). Esses dados comprovam que o retalho cutâneo fibular apresenta sensibilidade e especificidade elevadas para detectar alterações do fluxo sanguíneo decorrentes de obstrução das microanastomoses. Apesar disso, não tivemos nesse estudo um índice de sucesso elevado após a exploração das microanastomoses, ao contrário da expeririência de outros autores ${ }^{(2,5,6)}$ devido ao tempo with a skin graft. The maintenance of the posterior crural septum in the osteocutaneous flap of the fibula is not obligatory, and one or more perforators could be mapped with a Doppler ultra-sound and included in the flap. The presence of the posterior crural septum creates a larger protection for the flap, preventing the sprain of the perforator arteries. However it reduces the rotation arch hindering its positioning during the deepest reconstructions, such as the one of the femur and of the humerus. Another option to avoid the use of the posterior crural septum is include the perforators of the proximal or medial third of the leg that present a greater length and, therefore, a larger rotation arch.

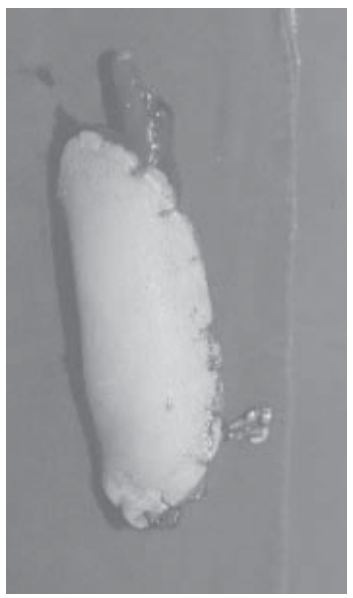

Figura 7 - Detalhe da fíbula vascularizada mostrando retalho cutâneo de grande dimensões para reparação simultânea da perda óssea e do revestimento cutâneo.

Figure 7 - Detail of the vascularized fibula showing a large cutaneous flap for the simultaneous repair of bone loss and cutaneous lining.

The bone scintigraphy and the serial $x$-rays were used, respective$l y$, as methods for the precocious and late evaluation of the viability of the vascularized fibula(1). Used with this purpose, the bone scintigraphy should be made until the end of the second week of the postoperative period, to avoid the effects of the revascularization of the bone graft generated by the creeping substitution. In that period the reception of the radiopharmaceuticals by the osteocytes demonstrates that the viability of the bone graft is dependent exclusively on the presence of blood flow due to penvious microanastomosis. The bone hypertrophy observed in the serial $x$-rays occur according to the principles of the law of Wolf, and it is only noticed when the fibula is viable (Figures 8, 9 and 10). The bone hypertrophy is less evident in the reconstruction of the bones of the forearm, unlike the observed in the femur, in the shinbone and in the humerus, where the serial $x$-rays clearly demonstrate that phenomenon. The bone consolidation was not used as a method for evaluation the viability of the fibula because it could occur even in the cases of microanastomosis obstruction. The analysis of the results showed a perfect correlation between the clinical outcome of the fibular cutaneous flap and the intra-operative findings. The bone scintigraphy and the serial $x$-rays were useful to corroborate those findings. The statistical study revealed that the sensibility and the specificity of the fibular cutaneous flap in the present study were, respectively, 98,6\% and $91,7 \%$ for a level of significance of $5 \%$ (Table 6). Those data prove that the fibular cutaneous flap presents elevated sensibility and specificity to detect alterations to the blood flow resulting from the obstruction of the microanastomosis. In spite of that, we didn't have a high success index in this study after the exploration of the microanastomosis, unlike the other authors' experience ${ }^{(2,5,6)}$, due to the prolonged time between the detection of the obstruction and the new surgery. In addition 
prolongado entre a detecção da obstrução e a reoperação . Além da sua eficácia, devemos ressaltar a ótima relação custo-benefício pois trata-se de um método simples que envolve acurácia e criatividade no emprego da técnica cirúrgica, rigor na vigilância pós-operatória, dispensando o uso de aparelhos importados sofisticados.
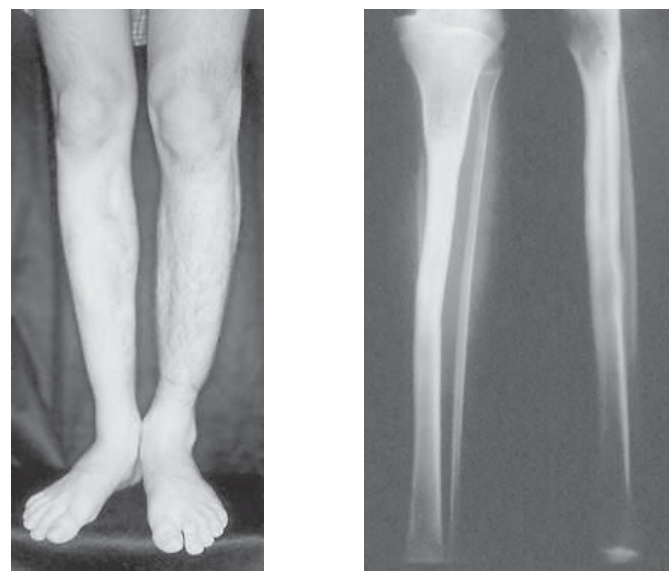

Figura $\mathbf{8}$ a,b - Aspecto clínico e radiográfico da hipertrofia da fíbula vascularizada em reconstrução da tíbia proximal.

Figure $\mathbf{8} \mathbf{a}, \boldsymbol{b}$ - Vascularized fibula hypertrophy's clinical and radiological aspect, in a reconstruction of the proximal tibia. to its effectiveness, we should emphasize the great cost-benefit relationship, because it is a simple method that involves precision and creativity in the study of the surgical technique, rigidity in the postoperative surveillance, sparingly usage of imported sophisticated apparatus.

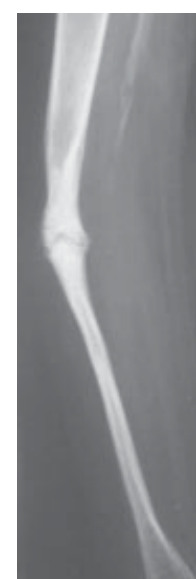

Figura 9 - Aspecto radiográfico da fíbula vascularizada mostrando ausência de hipertrofia óssea.

Figure 9 - Radiological aspect of the vascularized fibula, showing the absence of bone hypertrophy.
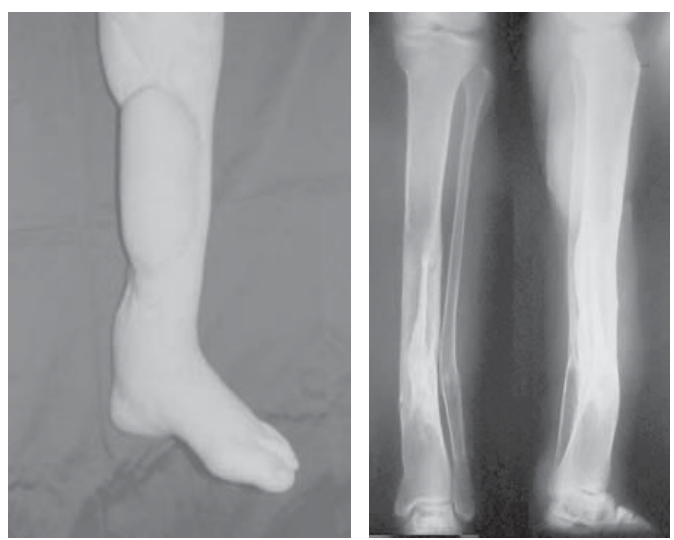

Figura 10 a, b. - Aspecto clínico e radiográfico de retalho osteocutâneo da fíbula mostrando integração do retalho cutâneo e hipertrofia óssea.

Figure $10 \mathbf{a}, \boldsymbol{b}$ - Clinical and radiological aspect of the osteocutaneous flap of the fibula showing the integration of the flap and the bone hypertrophy.

\begin{tabular}{|c|c|c|c|c|c|}
\hline S & E & VPP & VPN & RVS+ & RVS- \\
0,986 & 0,917 & 0,986 & 0,917 & 11,838 & 0,015 \\
\hline
\end{tabular}

S- sensibilidade / sensibility

E- especificidade / specificity

VPP-valor preditivo positivo / positive predictive value

VPN- valor preditivo negativo / negative predictive value

RVS + - razão de verossimilhança positiva / positive verisimilitude reason

RVS - - razão de verossimilhança negativa / negative verisimilitude reason

Tabela 6 - Resultados do estudo estatístico da correlação entre os desfechos clínicos do retalho cutâneo fibular e os achados intraoperatórios $(p<0,05)$.

Table 6 - Results of the statistical study of the correlation between the clinical outcome of the fibular cutaneous flap and the intraoperative findings $(p<0,05)$. 


\section{REFERÊNCIAS BIBLIOGRÁFICAS}

01. Bishop,A.T. Vascularized Bone Grafting. In :Green,D.P,, Hotchikiss, R.N., Pederson,W.C. Operative Hand Surgery. $4^{\text {th }}$ edition. Churchill Livingstone, 1999 p.1221-1250

02. Dissa,J.J., Cordeiro,P.G. Hidalgo,D.A.. Efficacy of Conventional Monitoring Techniques in Free Tissue Transfer: An 11-Year Experience in 750 Consecutive Cases. Plastic and Reconstructive Surgery, v.104(1):97-101, 1999.

03. Heitmann, C., Khan, F.N., Levin, L.S. Vasculature of the peroneal artery: An Anatomic Study Focused on the Perforator vessels. Journal of Reconstructive Microsurgery, v.19(3): 157-162, 2003

04. Jones, M.B Monitors for the cutaneous microcirculation. Plastic and Reconstructive Surgery, v.73(5):843-850, 1.984.

05. Khouri,R.K... Avoiding Free Flap Failure. Clinics in Plastic Surgery, v.19(4):773781, 1992.

06. Kin G.M. Buntic, R.F Buncke G.M. Cooper, TM, Siko, PP Buncke Jr. H.J. The effect of an Implantable Doppler Probe on the Salvage of Microvascular Tissue Transplants. Plastic and Reconstructive Surgery, v.101(5):1268-1273, 1998.

07. Shima,I., Yamauchi.S., Matsumoto,T., Kunishita,M., Shinoda, K., Yoshimizu,N., Nomura, S., Yoshimura, M.. A New Method for Monitoring Circulation of Grafted Bone by Use of Electrochemically Generated Hydrogen. Clinical Orthopaedics and Related Research, v.198:244-249, 1985
08. Swartz, W.M., Jones, N.F., Cherup, L., Alan Klein, B.S.. Direct Monitoring of Microvascular Anastomoses with the 20-MHz Ultrasonic Doppler Probe: An Experimental and Clinical Study. Plastic and Reconstructive Surgery, v.81(2):149-158, 1988

09. Torre, J.d.I., Hedden, W., Grant, III,J.H., Gardner,P.M., Fix, R.J., Vásconez, L.O. Retrospective Review of the Internal Doppler Probe for Intra-and Postoperative Microvascular Surveillance. Journal of Reconstructive Microsurgery, v.19(5):287290, 2003

10. Weiland A.J., Daniel R.K.: Microvascular anastomoses of bone grafts in the treatment of massive defects in bone. J Bone Joint Surg (Am) 61: 98-104, 1979

11. Yoshimura M., Shimamura K., Iwai Y., Yamauchi S., Ueno T.: Free vascularized fibular transplant, a new method for monitorizing circulation of the grafted fibula. J Bone Joint Surg (Am), v.65, p.1295-301, 1983

12. Zumiotti A.V.: Emprego do retalho osteocutâneo da fíbula nas reconstruções da tíbia. Rev Bras Ortop, 26(10): 345-49, 1991.

13. Zumiotti,AV \& Ferreira,MC: Treatment of congenital pseudoartrosis of the tibia by microsurgical fibula transfer. Micrusurgery 15:37-43,1994.

14. Zumiotti, A V., Wei T.H. e Ferreira M.C.: Treatment of Post-Tibial Osteomyelits Using Microsurgery Flaps. Journal of Reconstructive Microsurgery, 19(3):163-171, 2003. 